\title{
Penelitian Pendahuluan mengenai LKPD Model PBL terkait Kemampuan Berpikir Matematis
}

\author{
Maya Herlina $^{1 *)}$, Iden Rainal Ihsan ${ }^{2}$ \\ ${ }^{1,2}$ Universitas Islam Nusantara \\ ${ }^{*}$ mayaherlina@gmail.com
}

\begin{abstract}
Abstrak
Penelitian ini merupakan suatu penelitian desain (design research) dengan tujuan untuk merancang dan mengembangkan suatu desain Lembar Kerja Peserta Didik (LKPD) yang dapat mengatasi kesulitan dan mengoptimalkan desain LKPD. Tahapan design research yang dilakukan pada penelitian ini hanya tahapan penelitian pendahuluan (preliminary research). Pada tahapan tersebut peneliti melakukan analisis kebutuhan dan konteks, telaah literatur, dan proses pengembangan kerangka konseptual dan teoritis yang dalam hal ini perancangan dan pengembangan desain LKPD. Desain pemebelajaran yang merupakan hasil dari penelitian ini berupa produk LKPD untuk aktivitas peserta didik dalam pembelajaran. Umunnya desain ini deperileh adalah kegiatan perancangan LKPD yang diawali dengan review konsep atau materi terkait dan analisis kurukulum, kbutuhan serta konteks, perancangan LKPD, sehingga menghasilkan produk desain LKPD.
\end{abstract}

Kata Kunci: design-based research, LKPD, penelitian pendahuluan.

\begin{abstract}
This research is a design research with the aim to design and develop an LKPD design that can overcome difficulties and optimize the students' worksheet LKPD design. The stages of design research carried out in this study are only preliminary research stages. At that stage the researcher conducted a needs and context analysis, a literature review, and the process of developing a conceptual and theoretical framework in this case the design and development of the LKPD design. The learning design which is the result of this research is in the form of LKPD products for students' activities in learning. Commonly, this design is a DFS design activity that begins with a review of concepts or related material and analysis of curriculum, needs and context, LKPD design, so as to produce LKPD design products.
\end{abstract}

Keywords: design-based research, preliminary research, LKPD

\section{Pendahuluan}

Peranan matematika dalam dunia pendidikan sangatlah penting, karena matematika sebagai sumber dasar dari ilmu yang lain. Pembelajaran matematika di awali dengan belajar mengonstruksi sampai menyelesaikan fenomena atau persoalan yang baru. Proses pembelajaran pada abad 21 sudah semakin maju dan berkembang. Pembelajaran Abad 21 ini membawa perubahan-perubahan yang sangat populer salah satunya pada perkembangan ilmu pengetahuan dan teknologi (IPTEK) yang mengakibatkan terjadinya perubahan paradigma proses pembelajaran ditandai dengan perubahan kurikulum, media dan teknologi. Pendidikan di abad 21 merumuskan beberapa prinsip pembelajaran terkait perubahan paradigma yang harus dipenuhi, beberapa diantaranya yaitu dari berpusat pada pendidik menjadi berpusat pada peserta didik, dari satu arah menjadi interaktif, dari 
pemikiran faktual menjadi berpikir kritis, dan dari penyampaian materi menjadi pertukaran materi. Prinsip pembelajaran atau Pendidikan pada abad 21 memungkinkan tercapainya tujuan pembelajaran termasuk pembelajaran matematika.

Matematika merupakan mata pelajaran yang melatih pola pikir peserta didik secara sistematis dan logis. Hal ini sesuai dengan tujuan pemebelajaran matematika pada kurikulim 2013. Salah satunya kemampuan yang digunakan untuk memecahkan masalah matematika adalah kemapuan berpikir kreatif matematis. Dengan kemampuan berpikir kreatif mateatis, seseorang dapat mempelajari masalah yang dihadapi dengan merumuskan pernyataan yang inovatif. Pada kenyataannya, rendahnya krmampuan berpikir kreatif matematis peserta didik yang masih kurang terhadap pelajaran matematika dapat disebabkan karena beberapa faktor. Hasil observasi di sekolah tersebut ditemukan masih kurangnya buku pelajaran sebagai pegangan peserta didik untuk bisa dibawa pulang oleh masing-masing peserta didik. Selain itu, pihak sekolah belum memfasilitasi pembuatan LKPD, buku ajar/bahan ajar untuk peserta didik dalam rangka mengatasi kekurangan buku pelajaran. Pengembangan LKPD perlu dilakukan di sekolah ini karena LKPD dengan model PBL dapat melatih peserta didik untuk belajar berpikir kritis dalam memecahkan masalah Matematika.

Dari hasil wawancara disalah satu sekolah negeri di Kabupaten Bandung didapat bahwa peserta didik mengalami kesulitan dalam pembelajaran matematika. Peserta didik kurang aktif dalam menjawab soal yang mengharuskan menggunakan cara lain atau merumusakan konsep yang baru untuk memecahkan persoalan mastematika. Misalnya pada pembelajaran matematika wajib dengan materi pola barisan aritmatika dan geometri, sebagian besar peserta didik menjawab soal dengan menggunakan rumus yang telah baku dan kesulitan menggunakan cara lain selain prosedural.

Berdasarkan uraian diatas, dalam penyusunan LKPD diharapkan dapat menghasilkan kualitas LKPD yang baik dan dapat mengarahkan peserta didik untuk menyelesaikan permasalahan dalam proses pembelajaran agar tidak berpusat pada guru. Dalam hal ini LKPD dengan model pembelajaran problem based learning dinilai cocok digunakan dalam materi barisan untuk meningkatkan kemampuan berpikir kreatif. Selain itu, permasalahan tersebut dapat menuntut peserta didik untuk berpikir kreatif dan memonitor pemahaman mereka. Alternatif pendekatan pembelajaran yang dapat digunakan adalah Problem Based Learning (PBL). Hal tersebut didukung oleh hasil-hasil riset terdahulu yang mengungkapkan keunggulan PBL dalam membantu meningkatkan 
kemampuan berpikir kreatif pada peserta didik. (Uden \& Beaumont, 2006; Happy \& Widjajanti, 2014).

\section{Metode Penelitian}

Penelitian ini dilakukan di salah satu sekolah SMA kabupaten Bandung dengan fokus penelitian pada desain pembelajaran yang difokuskan pada lembar LKPD materi barisan dan deret. Penelitian merupakan suatu design-based research yang merujuk pada Plomp. Berdasarkan rujukan tersebut, tahapan yang dilakakan peneliti hanya tahap preliminary research yakni mengalisis kebutuhan dan konteks, telaah pustaka (studi literatur), dan proses pengembangan konseptual dan teoritis. Berikut ini adalah gambaran mengenai (fase) pada design-based research sebagai studi pengembangan menurut plomp dalam Ihsan\& Kosasih (2018), Ihsan \& Karjanto (2019) pada gambar 1.

Pada sub tahapan analisis kebutuhan dan konten, peneliti menelaah kembali dokumen kurikulum dan silabus untuk meteri barisan dan deret. Peneliti menganalisis kebutuhan pembelajaran berdasarkan indicator pencapaian kompetensi (IPK) yang terbuat pada rencana perencanaan pembelajaran (RPP). Selanjutnya, masih pada sub tahapan yang sama, peneliti menganalisis konten pembelajaran materi barisan dan deret yang dikaitkan dengan kosep kemapuan berpikir kreatif matematis. Untuk memperkuat analisis konten, peneliti menelaah kembali beberapa pustaka terkait barisan dan deret dan konsep-konsep pencacahan konsep mengenai desain pembelajaran penemuan terbimbing (Ihsan \& Iskandar, 2015[a]; Ihsan \& Iskandar, 2015[b]; Ihsan \& Saputra, 2015; dan Sulastri, dkk, 2015). Setelah telaah (studi) literatur selesai peneliti kemudian melanjutkan ke tahap pengembangan kerangka berpikir kreatif matematis yang diwujudkan dalam proses penyusunan LKPD. 


\begin{tabular}{|c|c|c|}
\hline $\begin{array}{l}\text { Preliminary } \\
\text { Research Phase: } \\
\text { a. Need and } \\
\text { context analysis } \\
\text { b. Review of } \\
\text { literature } \\
\text { c. Development } \\
\text { of a conceptual } \\
\text { or theoritical } \\
\text { framework for }\end{array}$ & $\begin{array}{l}\text { Developing or } \\
\text { Prototyping Phase: } \\
\text { Iterative } \\
\text { design, each } \\
\text { iterations being } \\
\text { microcycle of } \\
\text { research with } \\
\text { formative } \\
\text { evaluation }\end{array}$ & $\begin{array}{l}\text { Assesment Phase: } \\
\text { (semi-) summative } \\
\text { evaluation to } \\
\text { conclude whether } \\
\text { the solution or } \\
\text { intervention meets } \\
\text { the pre-determined } \\
\text { specifications }\end{array}$ \\
\hline
\end{tabular}

Gambar 1. Tahapan (fase) design reseach sebagai suatu studi pengembangan

\section{Hasil dan Pembahasan}

Pada penelitian ini diperoleh suatu hasil berupa desain LKPD dengan materi barisan dan deret aritmatika serta geometri pada bagian bahasan barisan aritmatika. Desain yang dimaksud merupakan desain awalyang ada pada tahapan desain based research selanjutnya akan diuji dan dikembangkan. Pada bagian ini akan dipaparkan penjalasan mengenai struktur desain LKPD yang menjadi temuan pada penelitian ini. Struktur yang di maksud terdiri dari kegiatan awal, kegiatan inti, dan kegiatan akhir. Adapun langkahlangkah rancanngan LKPD sebagai berikut.

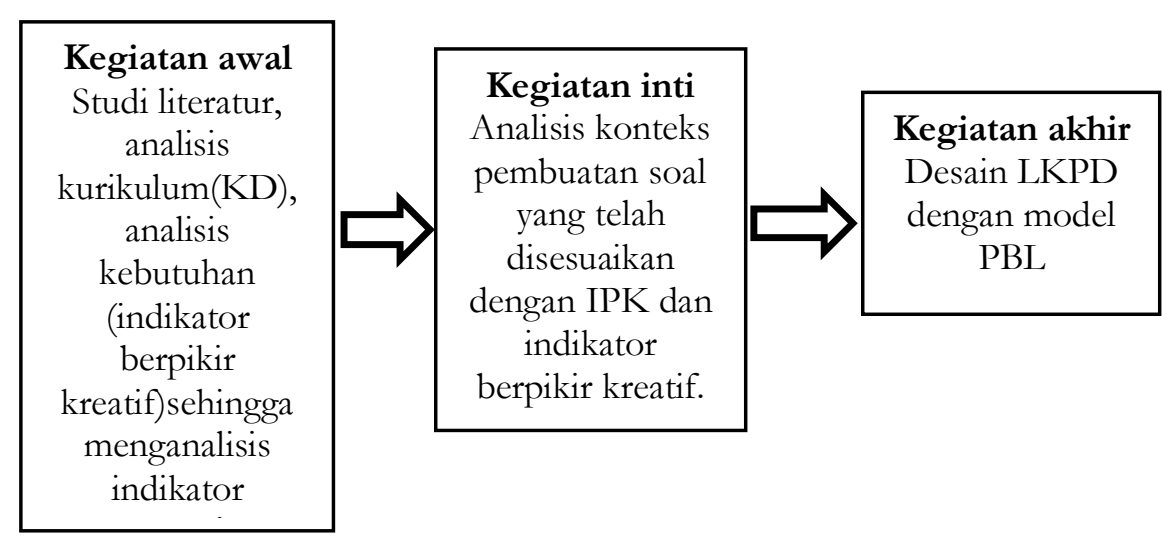

Gambar 2. Kerangka Desain LKPD

a. Kegiatan Awal

Pada kegiatan awal, dilakukan analisis kurikulum dan kebutuhan. Peneliti menelaah dan menganalisis kurikulum 2013. Analisis ini bertujuan untuk mengetahui materi yang diajarkan di kelas XI SMA pada semester genap. Salah satunya materi yang diajarkan pada semester genap yaitu barisan dan deret aritmatika serta geometri, tetapi peneliti dalam 
pendahuluan ini mengambil materi barisan aritmatika. Sehingga materi tersebut dijadikan sebagai materi untuk penelitian. Selanjutnya dilakukan analisis kebutuhan yang berupa kompetensi dasar(KD) yang termuat pada kurikulum 2013 yaitu silabus dan RPP di sekolah tersebut. Peneliti menelaah yang terkait dengan indicator berpikir kreatif dan materi barisan aritmatika. Setelah melakukan analisis kurikulum dan kebutuhan, kemudian dilakukan penjabaran indicator pencapaian kompetensi (IPK) yang telah sesuai dengan KD dan indicator berpikir kreatif. Dengan demikian study literatur selesai peneliti melanjutkan tahapan yang sesuai dengaan kkerangka pada desain LKPD. Berikut adalah contoh analisisk kurikulum dan kebutuhan yang telah peneliti susun.

\begin{tabular}{|c|c|c|c|}
\hline \multirow[b]{2}{*}{ No } & \multirow[b]{2}{*}{\begin{tabular}{|l} 
Analisis konteks \\
Kompetensi dasar
\end{tabular}} & PERTEMUAN KE 1 & \multirow[b]{2}{*}{ Indikator Pencapaian Kompetensi } \\
\hline & & $\begin{array}{l}\text { Analisis kebutuhan } \\
\text { Indikator Kemampuan } \\
\text { Berpilir Kreatif }\end{array}$ & \\
\hline \multirow[t]{4}{*}{1} & \multirow[t]{4}{*}{$\begin{array}{l}\text { 3.6 Menggeneralisasi pola bilangan } \\
\text { dan jumlah pada barisan Aritmatika } \\
\text { dan Geometri. }\end{array}$} & \multirow{2}{*}{$\begin{array}{l}\text { Menyelesaikan masalah dengan } \\
\text { satu cara kemudian dengan cara } \\
\text { lain dan memberikan penjelasan } \\
\text { tentang berbagai metode } \\
\text { penyelesaian itu (Fleksibilitas) }\end{array}$} & $\begin{array}{l}\text { 3.6.1 Menjelaskan semua metode yang } \\
\text { digunakan berkaitan dengan barisan } \\
\text { aritmatika.(C2) }\end{array}$ \\
\hline & & & $\begin{array}{l}3.6 .2 \text { Menentukan barisan aritmatika } \\
\text { suku ke-n dengan beberapa metode } \\
\text { berbeda.(C3) }\end{array}$ \\
\hline & & \multirow{2}{*}{$\begin{array}{l}\text { Memeriksa jawaban dengan } \\
\text { berbagai metode penyelesaian } \\
\text { dan kemudian membuat metode } \\
\text { baru yang berbeda (kebaruan) }\end{array}$} & 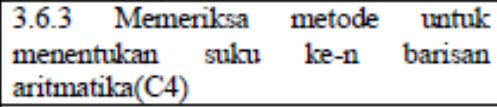 \\
\hline & & & $\begin{array}{l}\text { 3.6.4 Menentukan suku ke-n barisan } \\
\text { aritmatika dengan metode baru }\end{array}$ \\
\hline 2 & $\begin{array}{l}4.6 \text { Menggunakan pola barisan } \\
\text { Aritmatika atau geometri untuk } \\
\text { menyajikan dan menyelesaikan } \\
\text { masalah kontelsstual (termasulk } \\
\text { pertumbuhan, peluruhan, bunga } \\
\text { majemuk, dan anuitas) } \\
\text { C3 }\end{array}$ & $\begin{array}{l}\text { Menyelesaikan masalah dengan } \\
\text { bermacam-macam jawaban } \\
\text { (kefasihan) }\end{array}$ & $\begin{array}{l}\text { 4.6.1Menyelesaikan } \\
\begin{array}{l}\text { konstektual mengenai barisan } \\
\text { aritmatika. }\end{array}\end{array}$ \\
\hline
\end{tabular}

Gambar 3. Lembar Analisis Kurikulum 


\section{b. Kegiatan inti}

Pada analisis konteks, rancangan LKPD yang disusun berupa kebutuhan peserta didik yang dapat memfasilitasi untuk beradaptasi aktif dalam mengkontruksi kemampuan dan meningkatkan keterampilan peserta didik dalam menyelesaikan permasalahan yang berkaitan dengan kehidupan nyata. Peserta didik menginginkan LKPD dengan Bahasa yang mudah dipahami dan tidak ambingu, penjelasan permasalahan terperinci dan dapat dipahami, menarik, dan permasalahan yang diapakai dalam LKPD terkait persoalan matematika dalam konteks kehidupan sehari-hari.

Permasalahan yang diberikan berupa pernyataan-pernyataan yang saling terkait satu dengan lainnya. Maasalah yang diberikan diawali dengan ilustrasi gambar dan cerita, kemudian peserta didik diberikan pertanyaan-pertanyaan secara berurutan (bagian a,b,c, dan d). pertanyaan pertama (bagian a) adalah terkait dengan masalah-masalah yang sederhana dan khusus yang diaumsiakan dapat diselsaikan oleh peserta didik.

Pertanyaan selanjutnya diberikan untuk menjawab pertanyaan sebelumnnya. Peserta didik diarahkan untuk memeberikan jawaban di bagian a, kemudian peserta didik diharapkan untuk menjawab pertanyaan selanjutnya sehingga dapat menyelesaiakan permasalahan di bagian d. pada proses ini dilakukan diskusi dan menyelesaikan masalah. Kemudian pada tahap analisis ini untuk menentukan indicator perncapaian kompetensi terhadap materi barisan aritmatika dan disesuaikan dengan indikator kemampuan berfikir kreatif matematis. Berikut adalah contoh lembar analisis kontek yang telah peneliti susun. 


\begin{tabular}{|c|c|c|c|}
\hline \multicolumn{4}{|c|}{ Soal LKPD pertemuan 1} \\
\hline \multicolumn{4}{|c|}{ KEGIATAN 1} \\
\hline \multicolumn{4}{|c|}{$\begin{array}{l}\text { a. Dengan metode diskusi peserta didik mengolah indormasi-informasi yang ditemukan. lalu peserta didik memecahkan } \\
\text { (menentukan strategi penyelsaian) masalah untuk menentukan banyalknya kursi disetiap baris secara berurutan membentuk } \\
\text { suatu deret aritmatika. ( } 8 \text { menit) } \\
\text { b. Peserta didik menyelesaikan masalah LKPD kegiatan } 1 \text {, kemudian peserta didik menuliskan jawabannya pada LKPD } \\
\text { kegiatan } 1 \text { ( } 10 \text { menit) }\end{array}$} \\
\hline No & \begin{tabular}{c|c|}
$\begin{array}{c}\text { Indikator kemampuan } \\
\text { berpilis kreatif }\end{array}$ \\
\end{tabular} & $\begin{array}{c}\text { Indikator Pencapaian } \\
\text { Kompetensi }\end{array}$ & Soal \\
\hline 1 & \begin{tabular}{lr|}
\multicolumn{2}{l}{ Menyelesaikan masalah } \\
dengan satu cara \\
kemudian dengan cara \\
lain dan & memberikan \\
penjelasan & tentang \\
berbagai & metode \\
penyelesaian & itu \\
(Fleksibilitas).
\end{tabular} & 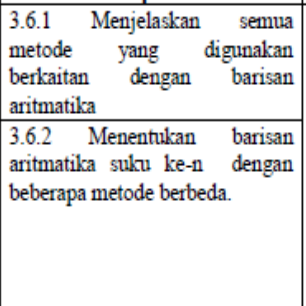 & $\begin{array}{l}\text { 1. Terdapat } 4 \text { buah kursi di Gedung bioskop pada barisan } \\
\text { terdepan. Banyaknya kursi pada baris-baris berikutnya selalu } \\
\text { lebih banyak } 3 \text { kursi dibanding baris sebelumnya. Jika terdapat } \\
8 \text { baris kursi, maka membentuk suatu barisan aritmatika. } \\
\text { a. Tentukanlah pola barisan aritmatika diatas. Sehingga } \\
\text { membentuk suatu urutan kursi dalam barisan. } \\
\text { b. Tentukan beda tiap barisan kursi bioskop tersebut. } \\
\text { c. Tentukan suku ke- } 5 \text { barisan aritmatika pada kursi bioskop. } \\
\text { d. Tentukan dan jelaskan banyaknya kursi bioskop } \\
\text { menggunakan } 2 \text { metode yang berbeda. }\end{array}$ \\
\hline \multicolumn{4}{|c|}{$\begin{array}{l}\text { Satu kelompok yang terpilih dipersilahkan untuk mempresentasikan hasil diskusi LKPD kegiatan } 1 \text { di depan kelas( } 5 \text { menit) } \\
\text { Peserta didik yang lain dipersilahkan untuk memberikan tanggapan dan atau pertanyaan pada sesi tanya jawab (2 ment) } \\
\text { Peserta didik diarahkan untuk menyimpulkan konsep barisan dan jumlah n suku pertama (deret) aritmatika( } 1 \text { menit) }\end{array}$} \\
\hline 2 & $\begin{array}{l}\text { Memeriksa jawaban } \\
\text { dengan berbagai metode } \\
\text { penyelesaian dan }\end{array}$ & $\begin{array}{l}\text { 3.6.3Memeriksa metode untuk } \\
\text { menentukan suku ke-n barisan } \\
\text { dan deret aritmatika }\end{array}$ & $\begin{array}{l}\mathrm{Di} \text { LKPD tidak ada soal mengenai metode kebanuan } \\
\text { munculnya di tes formatif }\end{array}$ \\
\hline & $\begin{array}{l}\text { kemudian membuat } \\
\text { metode baru yang } \\
\text { berbeda (kebaruan) }\end{array}$ & & \\
\hline \multicolumn{4}{|c|}{ KEGIATAN 2} \\
\hline \multicolumn{4}{|c|}{ Soal LKPD pertemuan 1} \\
\hline \multicolumn{4}{|c|}{ KEGLATAN 1} \\
\hline \multicolumn{4}{|c|}{$\begin{array}{l}\text { a. Dengan metode diskusi peserta didik mengolah indormasi-informasi yang ditemukan. lalu peserta didik memecahkan } \\
\text { (menentukan strategi penyelsaian) masalah untuk menentukan banyalnya kursi disetiap baris secara berurutan membentuk } \\
\text { suatu deret aritmatika. ( } 8 \text { menit) } \\
\text { b. Peserta didik menyelesaikan masalah LKPD kegiatan } 1 \text {, kemudian peserta didik menuliskan jawabannya pada LKPD } \\
\text { kegiatan } 1 \text { ( } 10 \text { menit) }\end{array}$} \\
\hline No & \begin{tabular}{c|}
$\begin{array}{c}\text { Indikator kemampuan } \\
\text { berpilis kreatif }\end{array}$ \\
\end{tabular} & $\begin{array}{c}\text { Indikator Pencapaian } \\
\text { Kompetensi }\end{array}$ & Soal \\
\hline 1 & \begin{tabular}{|lrr|}
\multicolumn{2}{|c|}{ Menyelesaikan } & masalah \\
dengan & satu & cara \\
kemudian & dengan & cara \\
lain dan & memberikan \\
penjelasan & tentang \\
berbagai & metode \\
penyelesaian & itu \\
(Fleksibilitas). &
\end{tabular} & 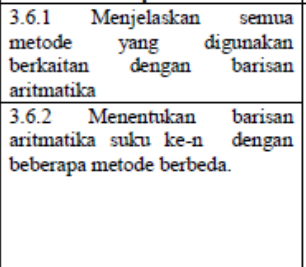 & $\begin{array}{l}\text { 1. Terdapat } 4 \text { buah kursi di Gedung bioskop pada barisan } \\
\text { terdepan. Banyaknya kursi pada baris-baris berikutnya selalu } \\
\text { lebih banyak } 3 \text { kursi dibanding baris sebelumnya. Jika terdapat } \\
8 \text { baris kursi, maka membentuk suatu barisan aritmatika. } \\
\text { a. Tentukanlah pola barisan aritmatika diatas. Sehingga } \\
\text { membentuk suatu urutan kursi dalam barisan. } \\
\text { b. Tentukan beda tiap barisan kursi bioskop tersebut. } \\
\text { c. Tentukan suku ke-5 barisan aritmatika pada kursi bioskop. } \\
\text { d. Tentukan dan jelaskan banyaknya kursi bioskop } \\
\text { menggunakan } 2 \text { metode yang berbeda. }\end{array}$ \\
\hline \multicolumn{4}{|c|}{$\begin{array}{l}\text { c. Satu kelompok yang terpilih dipersilahkan untuk mempresentasikan hasil diskusi LKPD kegiatan } 1 \text { di depan kelas( } 5 \text { menit) } \\
\text { d. Peserta didik yang lain dipersilahkan untuk memberikan tanggapan dan atau pertanyaan pada sesi tanya jawab ( } 2 \text { ment) } \\
\text { e. Peserta didik diarahkan untuk menyimpulkan konsep barisan dan jumlah } \mathrm{n} \text { suku pertama (deret }) \text { aritmatika ( } 1 \text { menit) }\end{array}$} \\
\hline \multirow{2}{*}{\multicolumn{2}{|c|}{\begin{tabular}{|l|l|} 
Memeriksa jawaban \\
dengan berbagai metode \\
penyelesaian dan \\
kemudian membuat \\
metode baru yang \\
berbeda (kebaruan)
\end{tabular}}} & $\begin{array}{l}\text { 3.6.3Memeriksa metode untuk } \\
\text { menentukan suku ke-n barisan } \\
\text { dan deret aritmatika }\end{array}$ & $\begin{array}{l}\mathrm{Di} \text { LKPD tidak ada soal mengenai metode kebaruan } \\
\text { munculnya di tes formatif }\end{array}$ \\
\hline & & & \\
\hline \multicolumn{4}{|c|}{ KEGIATAN 2} \\
\hline
\end{tabular}

Gambar 4. Lembar Analisis Konteks

\section{c. Kegiatan akhir}

Pada tahap kegiatan akhir desain LKPD dirancang sdengan KD, IPK, dan indikator berpikir kratif yang telah peneliti buat serta disesuaikan dengan model pembelajaran PBL. Desain ini dilaksanakan dengan tujuan untuk mengetahui rancangan LKPD yang sudah jadi, dan dapat digunakan oleh peserta didik. Selain itu desain LKPD ini dirancang mulai 
dari judul LKPD, Identitas, KD dan IPK, petunjuk LKPD, tahap orientasi, mengorganisaikan, membimbing, mengembangkan, menganalis dan evalusi. Hal tersebut disesuaikan dengan sintak pda model PBL. Berikut (pada Gambar 5) produk desain LKPD yang telah peneliti susun.

\section{Simpulan}

Berdasarkan pembahasan, terdapat beberapa simpulan yang diperoleh dalam penelitian ini. Dalam pembelajaran matematika, khususnya pada bagian materi barisan aritmatika kegiatan diawali dengan study literatur yakni analisis kurikulum dan kebutuhan, sehingga yang didapat dari penjabaran KD dan IPK untuk membuat pada analisis konteks yakni rancangan LKPD yang sesuai dengan indicator berpikir kreatif. Kegiatan berlanjut dengan membuat rancangan LKPD yang telah disesuaikan dengan IPK yang dukembangkan untuk melatih kemampuan berpkir kreatif matematis pada peserta didik kelas XI. Kegiatan selanjutnya dakah desain produk akhir LKPD yang telah dikembangkan dilihat dari segi isi, Bahasa, dan kegrafisan yang disesuaikan dengan model pembelajaran PBL untuk mengukur ketercapaian dan keaktifan peserta didik dalam pembelajaran menggunakan LKPD.

Berdasarkan temuan dalam penelitian ini, direkomendasikan hal yang dapat diteliti lebih lanjut. LKPD yang berbasis model PBL dapat dikembangkan dengan mengaitkan beberapa kecakapan matematika. Ragam metodologi dapat digunakan dalam mengkaji desain LKPD barisan aritmatika, salah satunya adalah desain research dalam tahapan yang lengkap.

\section{Referensi}

Happy, N \& Widjajanti, D.B. (2014). Keefektifan PBL DItinjau dari Kemampuan Berpikir Kritis dan Kreatif Matematis, Serta Self-Esteem Siswa SMP. Jurnal Riset Pendidikan Matematika, 1(1), 48-57

Ihsan, I.R., \& Iskandar, R.S.F. (2015). Model Pembelajaran Penemuan Terbimbing Tipe Minds, Suatu Alternatif Model Pembelajaran Untuk Membiasakan Peserta Didik Belajar Matematika Secara Mandiri. Makalah dipresentasikan pada Seminar Nasional Pendidikan Matematika Ahmad Dahlan (Sendikmad), Universitas Ahmad Dahlan, 27 Desember 2015

Ihsan, I.R., \& Iskandar, R.S.F. (2015). Membiasakan Peserta Didik Belajar Matematika Secara Aktif Melalui Model Pembelajaran Penemuan Terbimbing (Guided Discovery) dengan Tutor Teman Sebaya. Makalah dipresentasikan pada Konferensi Nasional Pendidikan Matematika 6, Universitas Negeri Gorontalo, 11 14 Agustus 2015. 
Ihsan, I.R. \& Kosasih, U.(2018). Penelitian Pendahuluan Mengenai Desain Pembelajaran Terkait Berpikir Kombinatorial. Prosiding Seminar Nasional Pendidikan Matematika Universitas Suryakencana (MINATKU), 131-136

Ihsan, I.R. \& Kosasih, U. (2018). Desain Pembelajaran Materi Permutasi Untuk Mengoptimalkan Kemampuan Berpikir Kombinatorial Mahasiswa Program Studi Pendidikan Matematika. Triple S (Journals on Mathematics Education), 1(2), 97106.

Ihsan, I.R. \& Karjanto, N. (2019). Optimizing Students Combinatorial Thinking Skill Through Design-based Research. Presented at International Congress on Industrial and Applied Mathematics 2019 at Universitat de Valencia, 15-19 July 2019.

Noptianus, A. \& Ihsan, I.R. (2018). Pengembangan Bahan Ajar Materi Trigonometri dengan Model Problem-Based Learning Untuk Meningkat Kemapuan Pemecahan Masalah Matematis Peserta Didik SMA. Triple $S$ (Journals on Mathematics Education), 1(1), 29-41

Saputra, S. \& Ihsan, I.R. (2015). Membangun Sikap Konstruktif Peserta Didik dalam Pembelajaran Matematika Melalui Model Pembelajaran Penemuan Terbimbing (Guided Discovery) Tipe MINDS. Makalah dipresentasikan pada Konferensi Nasional Pendidikan Matematika 6, Universitas Negeri Gorontalo, 11-14 Agustus 2015.

Sulastri, Y.L, Wahidin, D., \& Ihsan, I.R. (2015). Belajar Matematika Secara Aktif Melalui Model Pembelajaran Penemuan Terbimbing Tipe Bermain Peran (Role Playing). Makalah dipresentasikan pada Konferensi Nasional Pendidikan Matematika 6, Universitas Negeri Gorontalo, 11-14 Agustus 2015.

Uden, L. \& Beaumont, C. (2006). Technology and Problem-based Learning. London : Information Science Publishing (an imprint of Idea Group Inc). 